\title{
School Failure in Serbia ${ }^{1}$
}

\author{
Péter Radó ${ }^{2}$ \\ Expanzio Consulting Ltd., Hungary
}

The purpose of the paper is to enrich the policy discourse in Serbia on one of the most striking features of primary and secondary education: the high proportion of students who are failing in many different ways. The findings are mainly based on international comparative analysis that leads to the distinction among three European equity patterns: compensative education systems that are characterized by a high level of equity (low impact of background, weak selection) and high quality (above average student performance), selective education systems, in which low level of equity and high selection results in a below average overall student performance and attritive education systems (to which Serbia belongs together with most SouthEast European countries) that are characterized by high inequities and relatively poor average quality that at the same time results in a high proportion of failing students both in terms of participation and learning outcomes. The paper attempts to orient further empirical educational research by formulating assumptions about the underlying reasons of school failure and provides an analysis of the educational policy implications within the specific Serbian context.

Key words: comparative analysis of education, educational policy, attritive education, school, failure.

\section{Introduction}

The original intention of this paper was to assess the relevance of the OECD educational policy recommendations on equity (OECD, 2007) within the rather specific context of the education system of Serbia. However, in the course of processing this problem there was a shift of the purpose: from a contextualization of the OECD recommendations to a reflection on the actual conditions of combating school failure and the evidence based educational policy-making in Serbia. As a consequence, this study attempts to serve two equally important matters: (i) assessing the gravity of school

1 This paper is based on the presentation at two workshops on various OECD studies organized by the Centre for Educational Policy in Novi Pazar and in Belgrade on $22^{\text {nd }}$ and $23^{\text {rd }}$ February 2010.

2 e-mail: Rado@expanzio.hu 
failure in Serbia in international comparison and sharing a few insights on the possible underlying reasons, and (ii) assessing the actual systemic conditions of launching and implementing policy instruments that proved to have the potential of reducing school failure elsewhere. Obviously, within the limited space that a paper of this kind offers and on the basis of the limited amount of information that an "outsider observer" may have access to, nothing more can be created than a draft: a map of problems, all calling for further scrutiny and discussion. An additional purpose that this study may serve is transferring international experience. Countries in the close proximity of Serbia have (or had) very similar problems and experimented with many different solutions. The assessment of these solutions and confronting them with the circumstances in Serbia might be a valuable contribution.

The major sources of this paper are publicly available data of international comparative surveys and reports, the reports of international organizations active in South-East Europe, and various expert studies developed by the author of this study with the contribution of a large number of Serbian experts. ${ }^{3}$ Nevertheless, while searching for available data and research results, it became obvious that much more will be said in this paper about what we do not know than about what we really know and can support with hard evidence; as it will be seen, even basic statistical information of outstanding importance is missing or not available. Therefore, in relation to most matters addressed by the different sections of this paper, what can be offered is nothing more than suggesting questions for further research, as well as outlining a conceptual framework for analysis and discussion. What is obvious, though, is that the insight made possible by the already available information calls for efforts for deeper understanding provided by more empirical research.

\section{Preliminary explanations: the changing meaning of quality and equity}

The prevailing approach to education in Serbia is very much knowledgebased and progression-oriented; the bigger the factual knowledge that is acquired and the higher the level of formal education completed by students, the bigger the success ascribed to them. From a traditional point of view that emphasizes the inherent goals of education (such as the transmission of cultural heritage), it does not appear to be a problem. All teachers and

3 Lessons learned from the implementation of SEIP for the development of the education of Roma children. Report for the Roma Education Fund (2006 with Dejan Stankovic); Possible Areas for Co-operation between the Roma Education Fund and the Ministry of Education of the Republic of Serbia. Report for the Roma Education Fund (2009); Improving the inclusive capacity of schools in Serbia. Expert study for the DILS Program, Serbia. (2009); Inclusive Education Component of the DILS Program. Proposal for the DILS program (2009) 
managers of education at all levels grew up in an education system that was - and to a great extent still is - organized and operated accordingly; the requirements were remote and loosely determined, the teaching-learning process (not the expected outcomes) was regulated, the work of the teachers was controlled and a certain level of error was accepted (Radó, 2010).

The point of departure for the analysis on the following pages is that the performance of schooling cannot be judged on this traditional approach anymore. A several decade long accumulation of our knowledge about effective teaching and learning resulted in a rather dramatic educational policy paradigm shift in the second part of the nineties and in the first part of this decade. The framework of the new prevailing educational policy paradigm is the learning outcomes based approach to education that incorporates two parallel processes in the theory of educational policy: the gradual reconsideration of relevant knowledge in education (i.e. the shift of emphasis from prefabricated knowledge to applicable knowledge) and the development of the lifelong learning model (i.e. refocusing policies from teaching to learning, from education service providers to learning pathways).

The reconsideration of what we regard to be the relevant knowledge in education was triggered by various interplaying reasons, such as a growing emphasis on the instrumental aims of education (i.e. aims following from external economic and social references of education), the collapse of the knowledge monopoly of schools and the sudden emergence of easily accessible knowledge (e.g. on the internet) and the transformation of traditional academic frameworks for the structure of knowledge (as interdisciplinarity becomes the rule, the traditional structure of school subjects loses its relevance). Parallel to this, and as a consequence of the prevailing lifelong learning paradigm, educational policies have started to place stronger emphasis on learning and learners instead of on teaching and teachers. This led to a holistic approach to education systems that call for a stronger link between various levels and strands of education, and are poised to better adjust the supply of education services to the actual demand (CEDEFOP, 2003, Radó, 2009, Winch-Gingel, 1999).

Even the obvious must, occasionally, be emphasized: by learning outcomes, we mean something significantly different from what is meant by pure knowledge; what we imply here are competencies (i.e. knowledge, skills and attitudes) that open up avenues of additional learning opportunities and the successful application of knowledge in very diverse working and social contexts. According to a simple, but easily applicable definition provided by a CEDEFOP study "Learning outcomes are statements of what a learner knows, understands and is able to do after completion of learning." (CEDEFOP, 2008).

Parallel with the above shortly described developments, the meaning of quality of educational services was gradually changing. First of all, quality in education is not a simple matter of compliance with centrally determined 
standards anymore; the satisfaction of the "clients" (i.e. parents and students) and adjustments to the specific needs of the locality that schools are serving became equally important aspects. This diversification of the external references of quality made the concept very much contextual. The second conceptual change is the implication of the learning outcomes based approach. The growing complexity of the expected outcomes of education entails a more sophisticated understanding of the process of institutionalized learning that enriches the aspects of quality (See: Figure 1). Therefore, quality is less the feature of the results and increasingly that of the process. Educational outcomes (i.e. the effectiveness of education) compose only one aspect of the much broader concept of quality.

Figure 1: Quality and internal effectiveness in education (Radó, 2010)

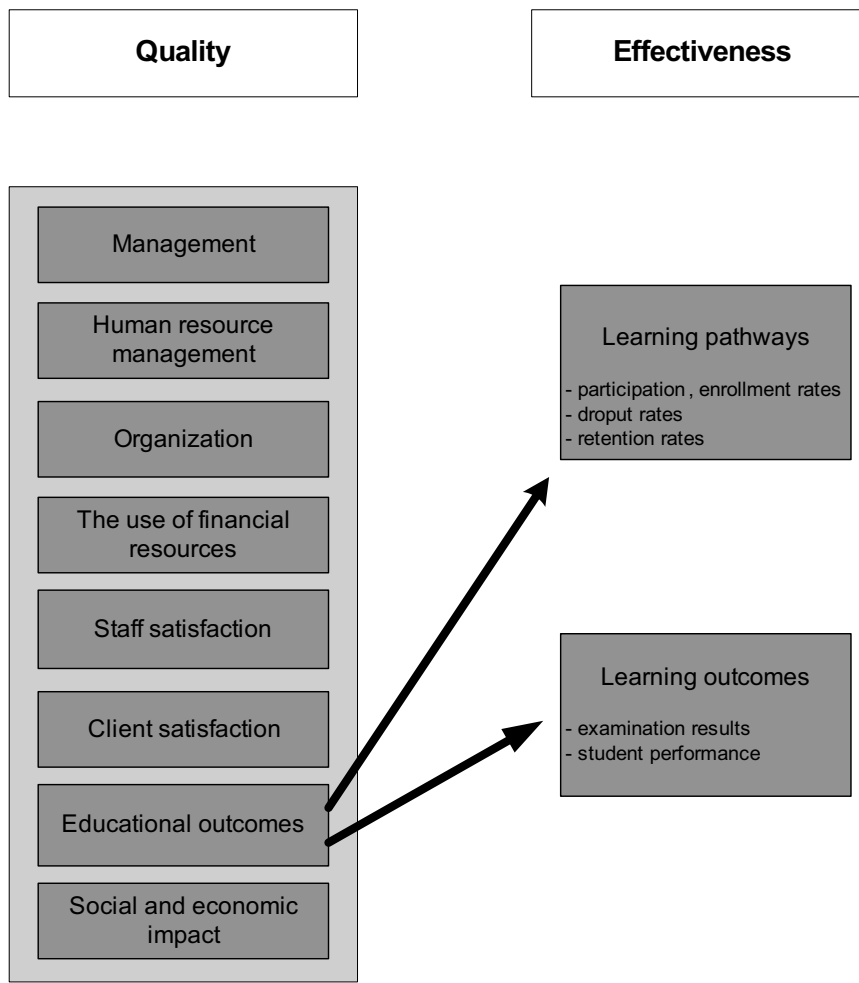

The already prevailing learning outcomes based approach gradually changed the way of thinking about educational inequalities as well. However, the jam of terms we use in relation to educational inequalities (for example, equality, equal chances, equity, integration, inclusion, combating the inverses of all these, and the widely used "for all" supplementing anything else) is one of the obstacles to informed policy discourse. Therefore, a very concise explanation of the conceptual basis of this paper is inevitable. 
For a long period of time inequalities were considered only in terms of access to educational opportunities for children with different backgrounds. Thus, the indicators that were applied in this respect were based exclusively on participation and progression data. However, the ever bigger emphasis on learning outcomes and the ever widespread external and standardized measurement of the performance of students led to a shift of emphasis from inequities in terms of participation to inequities in terms of learning outcomes (i.e. competencies). This shift is not independent from the fact that - with very few exceptions - the most developed countries made participation in uppersecondary education almost universal and largely expanded participation in higher education. The basic question in relation to educational inequalities is not the impact of students' background on progression in the education system; it is the impact on learning. This shift made our understanding of the way how social and economic disadvantages transform to school failure in the educational practice much deeper and more sophisticated. This new approach to inequalities is described as the equity of education, that is, the need to eliminate or minimize the shortcut between background and learning outcomes.

Figure 2: The shift from equal opportunities to equity

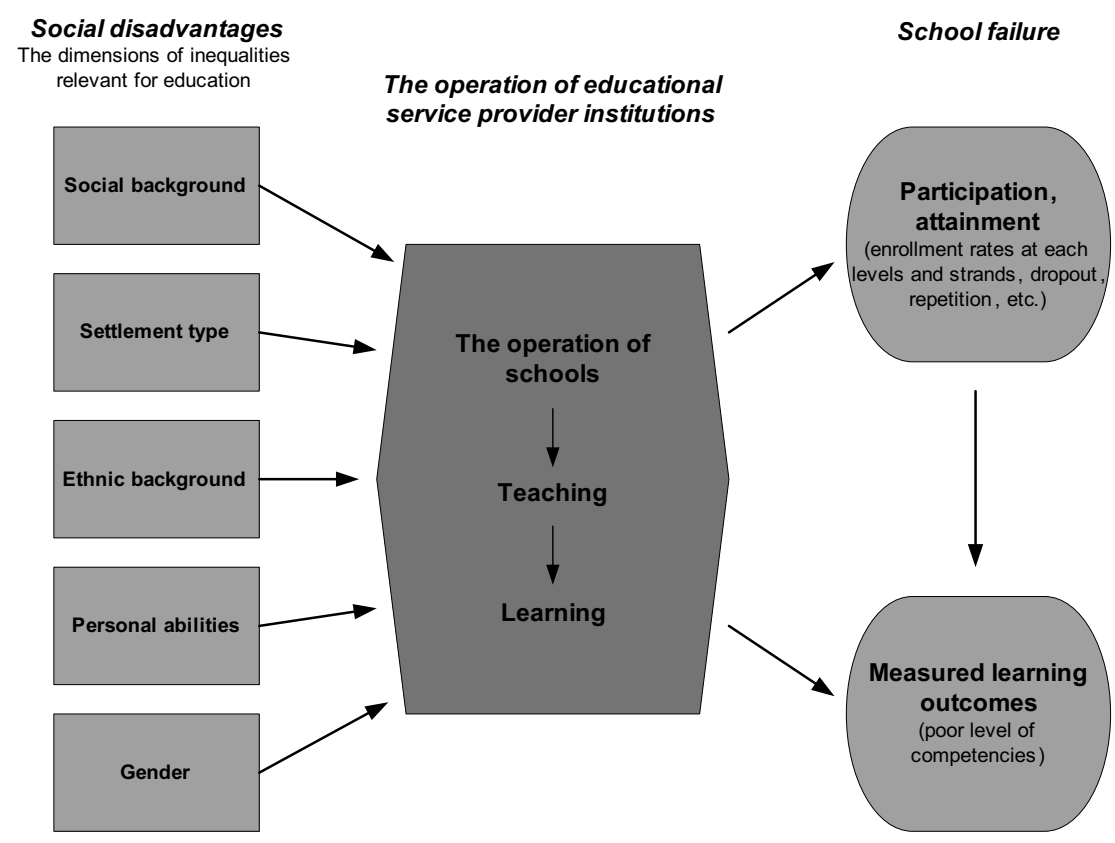

Equal chances

Equity 
The only reliable way to judge about the performance of a particular education system is international comparison. However, the validity of comparison should be a matter of great concern. For example, not so much can be learnt from an in-depth comparison between Korea and Serbia, or between Finland and Serbia, due to a large number of contextual differences. (It is even more misleading in the South-East European countries where the policy discourse is very much based on "examples" from the most developed Western-European countries instead of building on contextual analysis and deliberation). At the level of analysis, the validity of international references is better ensured if the education system of Serbia is compared with others within the same European region. This raises the issue of regional patterns: deeper analysis is more fruitful if there are regional patterns within which grasping similarities and differences brings us closer to better understanding of problems in one specific country. As the data on average reading literacy performance in a number of European countries show (Figure 3 ), there are visible regional similarities that - as it will be seen later - create distinct performance patterns. This is the reason why comparison with the other countries of the South-East European region is a powerful reference for Serbia.

Figure 3: Average reading performance of students in selected European countries. PISA, 2006

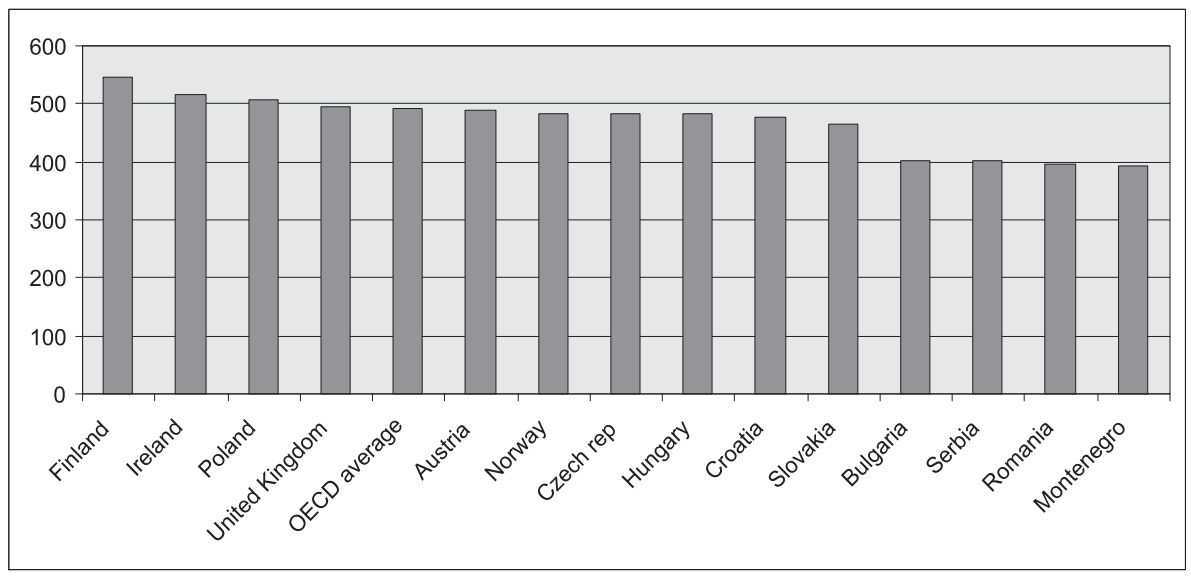

\section{The gravity of problems in Serbia}

The assessment of the relative performance of education systems is easy in the case of $36 \mathrm{OECD}$ and $27 \mathrm{EU}$ member countries where the information production capacity of education systems is adjusted to international cooperation frameworks allowing for cross-national comparison. However, the scarcity - in many cases the lack - of reliable comparative information for Serbia and other non-EU member countries of the South-East European region does not allow for more than an "educated guess". 


\section{Participation related problems}

According to the data of the Statistical Office of the Republic of Serbia, 93 per cent of those who started primary education in the school year 2000/01 managed to complete it on time. What is even more impressive, the data of the Statistical Office suggest that in the past few years more students were enrolled to secondary education than the number of those who completed the primary in the preceding school years. However, all experts agree that these data should not be handled without a great deal of scepticism. First of all, there is an unknown number of children who remain invisible for the statistical system, because they are not enrolled to education at all. They are most typically IDPs or children remaining invisible due to the dysfunctions of local municipality population registration and the population census. (A closer look into the population registry system makes this statement very much likely.) Even educated guesses are absent for the number of out of school children. The second problem is that almost nothing is documented. There are no accessible and reliable data on repetition and dropout rates or on transition from primary to secondary education. The more we dig deep into the statistical indicators of school failure, the more we acknowledge that nothing can be said with an acceptable level of certitude.

According to data submitted to the TransMonee database $4,81.6$ per cent of students are enrolled to any of the strands of secondary education. Even if we work with the rather brave assumption that this figure is reliable, almost one fifth of the children do not reach secondary enrolment. Who are these children and when do they drop out? Various research results and expert estimations suggest that a large proportion of children remaining invisible or dropping out of the system are Roma. According to the results of an UNDP survey (UNDP, 2005), the average duration of schooling for Roma is 5.5 years. The survey suggests that about one half of Roma children drop out already during the initial four years of primary education and an additional high number falls out at the point of shift from classroom teaching to subject teaching. Overall, out of the ten Roma children enrolled, only one completes primary school.

If our point of departure is the proportion of Roma children according to official statistics, it means that about one half of those who do not remain in formal education until secondary enrolment are Roma. However, certain "unofficial" estimations of the Ministry of Human and Minority Rights (OSI, 2007) figure the number of primary school aged Roma children more than four times bigger than the official data, so it may happen that almost all of the dropouts are Roma. Therefore, we may assume that the problem of dropout in Serbia is to a large extent caused by an extremely strong ethnic division, but we do not know exactly how much. However, the finding of the UNDP survey that the average duration of schooling of non-Roma population living in close proximity to Roma (i.e. most probably non-Roma with low social

4 UNICEF Innocenti Research Center, TransMonee database 2008. http://www.unicef-irc. org/databases/transmonee/ 
status) is 11 years establishes the plausible assumption that early school leaving is at least not a completely Roma-related problem. As a consequence, in international regional comparison, the proportion of those students who are enrolled to any tracks of secondary education is rather low (Figure 4).

Figure 4: Upper-secondary education enrolment rates, 2006/07 school year (per cent of population aged 15-18, ISCED 3, all programs)

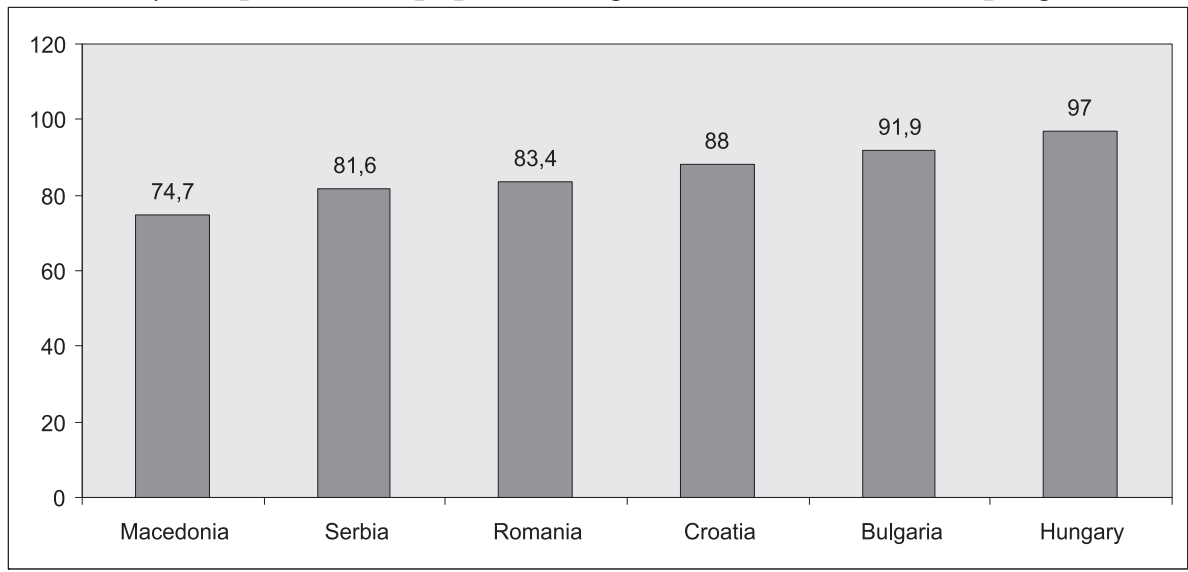

Source: TransMonee database

To sum it all up, the problem of school failure in terms of participation in education remains in blur; whatever we say, we say it by guessing on the basis of statistical data with questionable reliability and survey results with limited validity. Nevertheless, it is obvious that the magnitude of the problem is huge by any standards. For example, one of the EU benchmarks is the proportion of "early school leavers", that is, the proportion of those students who leave formal schooling without the completed secondary education (EU Commission, 2008). Contrarily, if we bear in mind that a certain number of children do not even enroll to schools in Serbia, it is not an exaggerated assumption that more than a fifth of the children do not even reach upper secondary education.

\section{Learning outcomes related problems}

As in the case of participation related matters, the only reliable measure of the performance of a particular education system is international comparison. Although Serbia did not participate in many international comparative student achievement assessment programs, the PISA survey of OECD gives very important signals about the performance of Serbian students.

By assessing the foundations of further learning, PISA provides a very important insight on the success of education systems in relation to the contemporary goals that they emphasize. In other words: PISA is not based on curricular foundations, it is based on basic external social and economic expectations towards education. 
As far as school failure is concerned, the most important PISA indicator of school failure is the proportion of those 15 year old students who perform at the level 1 or below. (The results are presented in a scale of proficiency levels that all compose distinct levels of the development of relevant competencies.) This PISA level indicates the lack of basic competencies, for example, functional illiteracy in the case of reading tests, that is, the proportion of those students who - in terms of their reading competencies - fall under the category of failing students. The proportion of these students in Serbia was extremely high already in 2003 (46.7 per cent) and became even higher in 2006 (51.7 per cent).

Figure 5: The proportion of 15 year olds with poor literacy competencies, 2006 (PISA proficiency level 1 or below)

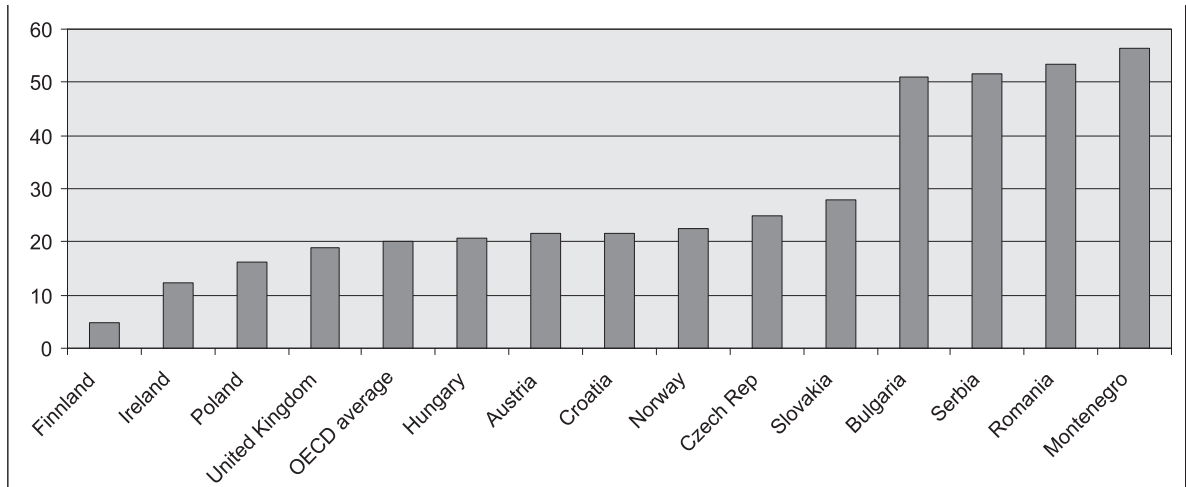

As these results demonstrate, there are clear regional similarities again. As in other South-East European countries, the proportion of students with very poor reading competencies is more than a half of those 15 year olds who are attending schools. As far as basic arithmetic competencies are concerned, the figures for Serbia are slightly better, but not to a significant extent; the performance pattern of the regional is salient, too.

Figure 6: The proportion of 15 year olds with poor mathematics competencies, 2006 (PISA proficiency level 1 or below)

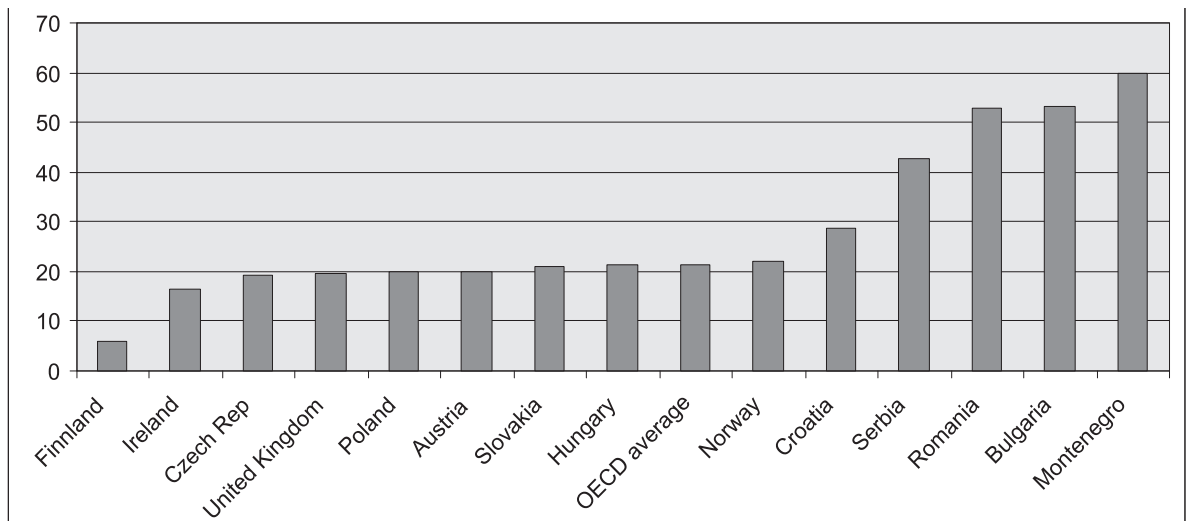


It is important to note here that the widely shared assumption in the CentralEastern European countries that relatively poor results of these countries are to a large extent caused by the performance gap between Roma and non-Roma students does not apply to Serbia. As it was already indicated, the large majority of Roma students drop out from education much earlier than the age of 15.

\section{The consequences of school failure}

The individual consequences of poorly developed basic literacy and mathematic competencies are as grievous as those of early dropout. First of all, they limit further learning chances to a huge extent. It does not refer only to the progression to any post-secondary education but also to any forms of learning necessary to obtain any qualifications or to update obsolete knowledge and skills. In general, low basic competencies impose a detrimental impact on all aspects of life: job opportunities, social relations, active citizenship, having access to services and to the use of technologies, performing parental roles, etc.

Inequities in education are widely regarded to be a value orientation dependent matter; therefore, there are periods when governments are very responsive to these problems and there are others when the weight of school failure on the policy agenda is much weaker. However, it is important to keep in mind that attention to school failure should not depend only on solidarity towards those who are at risk of failure; it is a problem that is the concern of everybody in Serbia. The reason for this is the community return to investment to education: higher employment rates result in a higher number of citizens contributing to the public cost that reduces the tax of individuals, as well as in less public money spent on social benefits or health services. The very strong relationship between educational attainment and almost all important spheres of social, political, economic and cultural life is well documented (OECD, 2007). Therefore, government intervention to combat school failure is not the interest only of those who actually suffer its consequences; the whole society is interested.

The problem of school failure is closely linked to the overall economic performance of Serbia. The large magnitude of school failure (low educational attainment and poor average basic competencies) may fit to a certain stage of economic development. For example, after the publication of the results of the first international adult literacy surveys in the second part of the nineties, economists discussed the consequences of "low literacy" and "high literacy" economies. This distinction suggests that in economies in which low literacy jobs are typical ones, the poor output of the education system may well fit to the demand on the labour market. However, in the long run, especially since the emphasis of labour policies shifted from employment to employability, poor basic competencies of the labour force became one of the most important obstacles to economic modernization. This is indicated by a very high rate of long-term unemployment among all unemployed in Serbia, which was 79 
per cent in 2005 (World Bank, 2007). Long-term unemployment is widely associated with weak employability caused by poor competencies.

Education does not serve the temporary actual needs of the labour market only; it should create the basic conditions of future development. In this perspective the significant reduction of school failure both in terms of participation and learning outcomes is one of the essential conditions for moving to higher stages of economic development (See: Table 1).

Table 1: The role of education in the stages of economic development (Schwab et alia, 2002, World Bank 2007)

\begin{tabular}{|c|c|c|c|}
\hline $\begin{array}{c}\text { Development } \\
\text { stage }\end{array}$ & $\begin{array}{c}\text { Key economic } \\
\text { challenges }\end{array}$ & $\begin{array}{c}\text { Focus of economic } \\
\text { production }\end{array}$ & $\begin{array}{c}\text { Education and labour- } \\
\text { market requirements }\end{array}$ \\
\hline $\begin{array}{c}\text { Factor-driven } \\
\text { growth }\end{array}$ & $\begin{array}{c}\text { Get factor markets } \\
\text { working properly to } \\
\text { mobilize land, labour } \\
\text { and capital. }\end{array}$ & $\begin{array}{c}\text { Natural resource } \\
\text { extraction, assembly, } \\
\text { labour-intensive } \\
\text { manufacturing. Primary } \\
\text { sector is dominant. }\end{array}$ & $\begin{array}{c}\text { Basic education, low-level } \\
\text { skills, disciplined work } \\
\text { habits. }\end{array}$ \\
\hline $\begin{array}{c}\text { Investment- } \\
\text { driven } \\
\text { growth }\end{array}$ & $\begin{array}{c}\text { Attract foreign direct } \\
\text { investment and imported } \\
\text { technology to exploit } \\
\text { land, labour and capital } \\
\text { and begin to link the } \\
\text { national economy with } \\
\text { the global economy. }\end{array}$ & $\begin{array}{c}\text { Manufacturing and } \\
\text { outsourced service } \\
\text { exports. Secondary } \\
\text { sector is dominant. }\end{array}$ & $\begin{array}{c}\text { Universal secondary } \\
\text { education, improved } \\
\text { secondary vocational and } \\
\text { technical education, life-long } \\
\text { learning to retool and update } \\
\text { skills, flexible labour markets } \\
\text { (easy entry, easy exit). }\end{array}$ \\
\hline $\begin{array}{c}\text { Innovation- } \\
\text { driven } \\
\text { growth }\end{array}$ & $\begin{array}{c}\text { Generate high rate } \\
\text { of innovation, and } \\
\text { adaptation and } \\
\text { commercialization of } \\
\text { new technologies. }\end{array}$ & $\begin{array}{c}\text { Innovative products } \\
\text { and services at the } \\
\text { global technology } \\
\text { frontier. Tertiary sector } \\
\text { is dominant. }\end{array}$ & $\begin{array}{c}\text { education, especially in } \\
\text { science and engineering } \\
\text { specializations; high rates } \\
\text { of social learning, especially } \\
\text { science-based learning; } \\
\text { dynamic R\&D sector linking } \\
\text { higher education programs } \\
\text { and innovating firms. }\end{array}$ \\
\hline
\end{tabular}

Since this paper focuses on those stages of formal schooling when school failure is generated, the coverage and quality of secondary education and participation in adult learning is beyond its scope. (Obviously, the failure in early stages inevitably leads to radically reduced learning chances in later stages.) However, even a very short discussion on the magnitude of school failure related problems in Serbia may indicate that the educational conditions of investment driven economic growth are not completely in place in Serbia.

\section{The underlying reasons for school failure}

\section{Equity profiles}

When trying to grasp the magnitude and underlying reasons of school failure in primary and secondary education, we should be very much aware that the indicators that have been discussed so far are proxies: they are very instrumental 
in identifying ("indicating") problems, but these problems are always much more complex than the grasp of indicators. Therefore, providing very rough estimations about the gravity of problems is far from being enough to jump to the discussion on the necessary therapy. The complexity of underlying reasons should be understood for the design of the appropriate policy interventions. The first step to be made in understanding the reasons for school failure is digging deeper into the performance profile of the Serbian education system.

The first and a very much policy relevant question to be answered is whether we are dealing with an equity problem (i.e. the detrimental impact of the disadvantaged student background on the effectiveness of learning) or a quality problem (i.e. the detrimental impact of poor quality teaching on learning, irrespectively of the background of students). From an equity point of view, two aspects require closer scrutiny: (i) the impact of students' background on their performance and (ii) the extent to which education systems are selective.

The first aspect is the impact of economic, social and cultural background; in other words: are the schools able to compensate for disadvantages or are they rather intensifying their negative impact on student performance? For this question, the analysis of the results of the PISA survey is very much instructive. What might be surprising when comparing a few selected European countries (Figure 7) is the fact that the impact of the background of the 15 year old students is equally low in the best performing countries (such as in Finland and Ireland) and in the South-East European countries that perform under the average of the most developed countries. (The only exception is Bulgaria, where this impact is even higher than in the CentralEuropean countries, where education systems are not able to compensate for the detrimental impact of the disadvantaged background.) At first sight, Serbian schools perform better in this respect than the average compensation capacity of education in the developed countries.

Figure 7: Relationship between student performance in reading and the PISA index of economic, social and cultural status (ESCS) 2006.

(Score point difference associated with one unit on the ESCS)

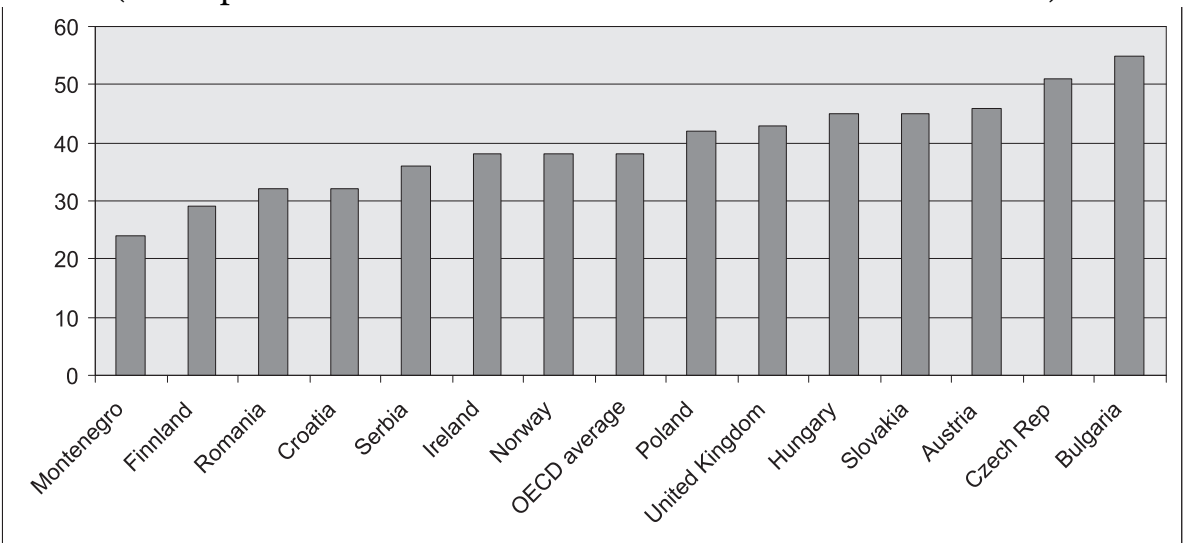


The other aspect of equity, that is, the selective character of education systems, requires some explanations. First of all: there are no selection free education systems. At various transition points if the number of applications to a certain school exceeds the number of seats, selection is inevitable. The question is: how fair is the selection procedure? We are talking about "selective" education systems if the background of students - and not their talents and diligence - determines their enrolment chances. The reason why selection is an important aspect of equity lies in the fact that in homogeneous classrooms the average performance of students - and, especially, the performance of disadvantaged students - is lower (OECD, 2007). Therefore, selection (i.e. the distribution of children into homogeneous classrooms according to their social, ethnic or cultural background) further reduces the capacity of schools to compensate for the negative impact of disadvantages on learning.

It is the analysis of the results of the PISA survey again that offers an insight on the extent to which different European education systems can be described as selective. The comparison of the variance of performance of students within schools and among schools well indicates the extent of selection; in countries where within school differences are higher, the classrooms are heterogeneous, and vice versa. As Figure 8 shows, the less selective education systems operate in the high performer Northern and North-Western European countries, while the most selective education systems are the Central-European ones. In the South-East European countries between school and among school variance of student performance is rather balanced, which suggests a much weaker selection than in the Central-European countries (with Bulgaria as an exception, again).

Figure 8: Between-school and within-school variance in student performance on the reading scale in PISA, 2006

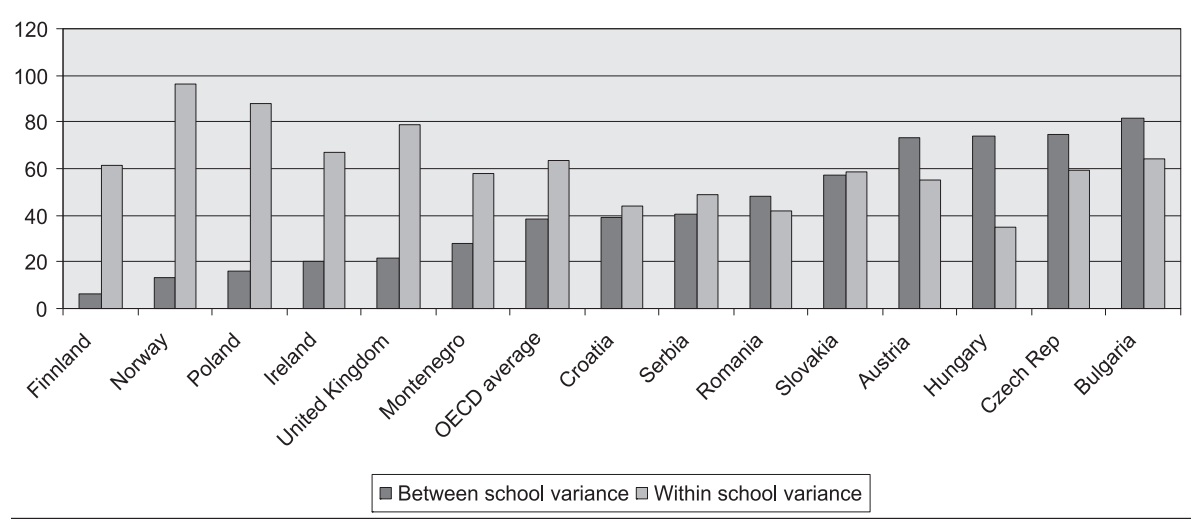


However, it is important to keep in mind that this picture is very much misleading. Earlier in this paper we came to the rough estimation that a large proportion (about one fifth) of the students are not in formal schooling anymore at the age when PISA measures. In other words, the most "problematic" students simply do not influence the PISA performance profile of Serbia. But even in the absence of these students, the proportion of very poorly performing 15 year olds is extremely high, which is indicative of serious quality problems.

Generally speaking, on the basis of the so far described profiles of educational outcomes, we can identify three patterns in Europe. (For the sake of simplicity of the discussion, the countries of the Mediterranean WesternEuropean region will remain out of the following patterns.) The first pattern is that of the compensative education systems, which are characterized by a high level of equity (low impact of background, weak selection) and high quality (above average student performance). This pattern well describes the education of Finland or Ireland. The second pattern is that of the Central European countries: the selective education systems, in which low level of equity results in a below average overall student performance, in spite of very well performing segments of these education systems (mainly general secondary education). The third pattern is that of the attritive education systems of most South-East European countries that are characterized by high inequities and poor average quality at the same time that results in a high proportion of failing students, both in terms of participation and learning outcomes.

\section{Hidden mechanisms in work}

When digging deeper into the characteristics of the attritive Serbian primary and secondary education system, further comparison with other countries with similar performance profiles brings us closer to the better understanding of the problems in Serbia. As Figures 7 and 8 indicate, the negative impact of the background of the students on learning and the selective character of the education system is stronger in Bulgaria than in Austria, Hungary or the Czech Republic. In a very specific sense, the unfavourable picture that PISA creates about equity in the Bulgarian education system is the result of its relative success in retaining students longer in formal schooling; enrolment to secondary education is approximately ten per cent higher in Bulgaria than in Serbia. Most probably, this stronger retention capacity is not independent from the higher pre-primary enrolment rate in Bulgaria (in the school year 2006/07, it was 73.9 per cent in contrast to the 49.1 per cent in Serbia $^{5}$ ) and the relatively high quality of the initial phase of primary education, as indicated by the results of the 2006 PIRLS survey. (PIRLS measures the reading literacy competencies of students at the end of

5 TransMonee data base. 
the 4th grade of primary education.) The fact that the Bulgarian education system produces fewer failures in terms of participation and approximately the same proportion of functional illiterate 15 year olds - that includes the performance of a much higher proportion of disadvantaged children suggests that the quality related problems are slightly less serious in Bulgaria than in Serbia. Contrarily, in Romania, higher pre-primary enrolment does not result in a much higher student retention than in Serbia, due to the poor effectiveness of the first four years of primary education (See: Table 2). Serbia did not participate in the PIRLS survey. Nevertheless, the comparison with the same figures for Macedonia offers a guess; lower than the Serbian preprimary enrolment rate and poorer PIRLS results than in Romania lead to a lower retention capacity than in Serbia. There is as high probability that the effectiveness of the initial phase of primary education in Serbia is somewhere at the level of Romania and Macedonia.

Table 2: Factors contributing to the retention capacity of four South-East European education systems

\begin{tabular}{|c|c|c|c|c|}
\hline Indicator & Bulgaria & Romania & Macedonia & Serbia \\
\hline $\begin{array}{c}\text { Pre-primary en- } \\
\text { rolment rate } \\
\text { (2006/07) }\end{array}$ & 73,9 & 75 & 39,6 & 49,1 \\
\hline $\begin{array}{c}\text { PIRLS 2006 average } \\
\text { score } \\
\text { (rank out of } 45 \\
\text { countries) }\end{array}$ & 547 & 489 & 442 & - \\
\hline $\begin{array}{c}\text { Retention: secondary } \\
\text { enrolment rate } \\
\text { (2006/07) }\end{array}$ & 91,9 & 83,4 & 74,7 & 81,6 \\
\hline
\end{tabular}

Sources: TransMonee database and PIRLS 2006.

Even if we assume that the indicators that provide signals about the preparedness of children for schooling (pre-primary enrolment) and about the development of basic learning skills (PIRLS results) are major factors contributing to educational successes or failures at later stages of schooling, these signals should be interpreted with a great deal of cautiousness for three reasons. First of all, as it was mentioned already, the reliability of statistical data is questioned by most experts in most of the SEE countries. The margin of error of statistical data might be big enough to overwrite the conclusions that flow from this very basic and simple comparison. The second reason for cautiousness is the fact that PIRLS and PISA do not measure the same things; the underlying framework of measurement for PIRLS comprises common elements extracted from the curricula of the participating countries, while PISA is based on its own framework: the definition of measured competencies for the sake of PISA itself. For example, it is very much likely that the relatively good performance in PIRLS (10 year olds) and the poor performance in PISA (15 year olds) in Bulgaria are partly explained by the fact that Bulgarian 
curricula are not oriented towards the development of basic competencies as they are widely understood in the international literature. The third reason for precaution in drawing far-reaching conclusions is that the pedagogical success of classroom teaching is not the only factor contributing to the improved retention capacity of schools. (As it will be discussed later, the vested interests of schools and municipalities are almost as important.)

Everything that was said so far about the possible reasons for school failure in Serbia might be instrumental in determining concrete policy objectives and the targets of policy intervention. However, without a sound and well-documented understanding of the underlying reasons, the manner of intervention (i.e. the relevant policy instruments) can hardly be identified. The comparison of the performance profile of these South-East European countries offers a plausible conclusion: the more successful initial phase leads to higher secondary enrolment rates at the expense of increased selection. In other words, the increased retention capacity of education does not necessarily mean that subject teaching in the second phase of primary education and in secondary education becomes more successful in the development of basic competencies for all children. It suggests that improved retention with persistent quality problems may transform the typically attritive character of Serbian education to a selective one, as is the case in Bulgaria, where the magnitude of school failure - as it is measured by PISA - is not lower than in Serbia. This hypothesis could be proved if we had a good understanding about the reasons of strong attrition in Serbia embedded into the features of the teaching-learning process in schools. But we do not have this understanding; due to the lack of extended empirical pedagogical research aiming at revealing the reasons for poor PISA results, schools remain "black boxes". (It also applies to Bulgaria where very similar PISA results did not lead to increased research efforts and intensive professional discourse, as it happened in most CentralEuropean countries after the so-called "PISA shock".)

Due to the lack of evidence, we should rely on "evidence substitutes": the widely shared views of experts based on their experience of working with schools and the results of empirical education research in other countries. Even with the help of these surrogates, what can be presumed about the pedagogical reasons for failures is not very much more than reasoning backwards from what we know about the results of teaching - mainly on the basis of evidence from elsewhere. The underlying assumption for this is that the shortcomings of the educational practice leading to high selection pressure and high rates of failing students are basically the same in the Central-European countries and in Bulgaria as those of high school failure in Serbia. (This is an assumption that the already existing or future empirical research results should prove or disprove.)

As far as the school-related reasons for educational failures are concerned, the two determining shortcomings are most probably rooted in the prevailing patterns of teaching and the prevailing organizational operation of schools. 
Teaching. When talking to experts in Serbia, most of them agree that the most important features of teaching practice are the lack of "individualization" and the elitist expectations of teachers. It is important to note here that the use of the term "differentiation" is not always unambiguous in Serbia; sometimes it is applied to organizing ability groups, which is very far from its real meaning. In fact, from the perspective of the results, the meanings of individualization and differentiation (as understood in international education science) are not different. However, from the point of view of teaching practice, they are: while individualization implies individual and different treatment of children, differentiation means the enrichment of content (not only a single textbook prevails), instructional methods (alternative and multiple ways of managing and organizing learning in the classroom) and multiple ways of pedagogical assessment for multiple purposes (diagnostic, formative, summative pedagogical assessment). Differentiated teaching is working with the entire classroom in a way that allows for each individual child to learn in spite of their very different talents and learning styles. In a sense, it is about mastering the entire methodological repertoire of teaching (Tomlinson, 1999). It is a widely agreed observation in Serbia that the huge majority of teachers rely very much on prefabricated and pre-structured knowledge of the textbooks, they rarely use other instructional methods than "frontal teaching" and their assessment practice rarely goes beyond marking for summative purposes. As far as the expectations of teachers are concerned, they are very much driven by the underlying cultural code of the "mandatory content" that is identical with that of the educated middle class (i.e. the intellectual elite). Content is regarded to be the goal of education and not one of the components of a complex set of developmental objectives (i.e. competencies) within which the selection of content should be adjusted to the purpose. (The author of this paper has no access to the results of any representative empirical pedagogical research on teaching practice in Serbia, so he is relying on the views of Serbian experts.) It is important to bear in mind that it is not only the official curriculum that forces teachers to focus on one single set of intellectual knowledge; teachers are intellectuals themselves, their own cultural code is the curriculum. One of the side effects of elitist expectations towards the learning of students is a strong exclusion of those who are not equipped with this language and cultural code at home. It is further strengthened by the so-called "Pygmalion effect": the expectations of teachers towards students are self-fulfilling prophecies (Rosenthal \& Jacobson, 1968). The combined impact of very traditional teaching and elitist expectations dooms to failure those children who would not be successful anyway.

Schools. Schools are not simply buildings where teachers and students meet on a regular basis without the disturbing impact of actual weather conditions and that ensure the logistical/technical conditions for teaching. Learning 
successes or failures cannot be attributed to individual teachers only; they are the results of work of the entire school. In theory, the organizational operation of schools should strengthen the unified impact of the work of individual teachers by ensuring cooperation among those who teach the same children and should mediate between external expectations and lonely classroom work of teachers. In addition to this, these are the schools that should operate those institutionalized mechanisms that are able to identify the students at risk of failure and should institutionalize those educational protocols aiming at preventing failures. Therefore, from the point of view of various school failures, how schools are working is equally important as the way teachers are teaching. The two key organizational elements in this respect are organizational reflection (i.e. confronting the results with expectations in order to identify problems) and institutionalization of solutions (i.e. initiating organizational changes in order to make the solution work). Several Serbian experts agree that these characteristics are rather weak in operations of schools: self-evaluation is already mandatory but did not become a wide regular practice in the huge majority of schools so far, and sporadic pedagogical innovations typically remain the "private matters" of individual teachers or a small group of teachers.

All these typical characteristics of educational practice - although with minor differences in emphasis - can apply to most South-East European countries and - with a different magnitude of the shortcomings - to the Central-Eastern European countries, too (Radó, 2010). However, the specific contextual issues contributing to these very general reasons might be very different and deserve serious scrutiny. (The level of analytical generality of this paper does not even allow for mapping out the relevant contextual matters. However, when testing the overall policy relevant assumptions of this paper, large amount of evidence should be gathered on a wide range of causes and effects.)

The results of these shortcomings are more or less clear: a strong pressure to create homogeneous classes that are easy to teach with very traditional teaching in very traditional schools. The way to achieve this is different in attritive and in selective education systems: allowing children to drop out in Serbia and Romania, and sorting children to low added value dead end tracks of secondary education in the Czech Republic and in Hungary. (Of course, the distinction refers to idiosyncrasies; for example, tracking Roma students to special education is a widely used practice in Serbia and the dropout rate in secondary vocational training is still high in Hungary.) The attritive character of education in Serbia has major consequences for the education of Roma children. While in Central-Eastern European countries (the Czech Republic, Hungary and Slovakia) the big selection pressure combined with biased expectations towards Roma children and pressure from the outside ("white flight") results in segregation of Roma students, in Serbia the same bias and external pressure result in enormous dropout rates among Roma students. 


\section{Reasons external to the schools}

The next question to be answered refers to the reasons of the different magnitude of school failure related problems in South-East and Central Europe. So far it has been suggested that the roots of school failures are similar but the gravity of the underlying problems is different. In other words, in all appearances, quality of schooling is poorer in South-East European countries than in the Central European ones. To a certain extent, that might be the case, but in fact, we do not know. However, what we do know is that there are large differences in terms of the systemic environment within which schools work (Radó, 2010). These differences are probably much bigger than the differences between the style of teaching and the work of schools.

The point is that schools alone cannot be blamed for a large number of failing students if their shortcomings are matched with a wide range of governance failures. If schools are not expected to perform at the level of a minimum standard, if they do not reflect on the results and the quality of service they offer, if they are not made interested in avoiding failures, if they do not have access to the required human and financial resources and they do not receive the necessary external professional support, governance of education has its large share in the responsibility for school failure.

As far as the governance of education in Serbia is concerned, many of these requirements are not ensured. First of all, failures are not made visible; therefore, schools with extremely high dropout rates and with a big proportion of students with undeveloped basic competencies can do their daily business undisturbed. Since inspection is oriented towards control of teaching and not towards contrasting schools with their services results, it does not help a lot. It is not able to do so, not only because inspectors are subjective and are not school evaluation specialists, but also because they themselves are poorly equipped with the necessary information, such as the dropout figures for each school. (We do not know what kind of information is provided to the Regional Departments by the Education Information System since these data are not public.) Even out of school children remain invisible, because population registry operated by municipalities is not in a very good shape and municipalities have very little to do with the management of education anyway. In addition to all these, although there are approved performance standards for the eighth grade in three subjects, they are designed to mediate between the curriculum ("Plan and Program") and the daily assessment practice of teachers. Therefore, the achievement of students is not measured at all on a regular and systematic basis. In fact, the only feedback provided on the performance of students comprises marks awarded by teachers, but this reflects much more the assessment practice of teachers than the competencies of students. If all learning failures remain hidden, it is very easy to shift the 
responsibility for the obvious cases of failure to anyone outside school, most typically to parents and children.

The other governance failure to be mentioned is the fact that school failures of any kind have no consequences. Of course, it would be very much premature to argue for a sophisticated performance management system in Serbia. (Building the institutional and professional conditions, such as a contemporary external evaluation mechanism, a regular external assessment of students' performance, the mechanisms of developmental intervention in identified underperforming schools and the like would be the matter of a decade long systematic investment.) However, due to the above described attritive character of the Serbian education system, more basic instruments should be applied first: connecting financing with the number of students that schools are serving. In the actual system, schools are directly financed on a "historical basis" (on the basis of the previous year budget) by the central state budget. In this system none of the relevant local actors (municipalities, schools and teachers) have a vested interest in enrolling all possible children and retaining them through the entire program they offer. To put it simply: actually, schools are funded regardless of the task they perform.

In contrast to this old-fashioned financing system, most European countries allocate resources to schools through a normative mechanism. Especially, per capita based indirect financing (financing schools through municipalities) has the proven potential to make service providers interested in enrolling and retaining students by two of their characteristics: (i) the amount of money deployed to education is determined by the number of students who are enrolled to schools, and (ii) it makes budget constraint for municipalities hard and they roll over to the financial management of schools, that is, they force the schools to reduce their capacities if the number of children declines. As far as students' retention is concerned, it really works; in the Central European countries (such as Hungary) that started to move to a per capita based decentralized financing system two decades ago, dropout rates were declining throughout the entire nineties since schools were under the pressure of the declining number of students due to demographic reasons (Bischoff, 2009, Radó, 2010). Therefore, the already decided shift to a new financing system in Serbia is not simply a way of ensuring basic efficiency requirements; it also serves well the genuine educational objectives of outstanding importance.

As far as the responsibility of government in Serbia is concerned, probably the first thing that comes to the mind of most people is the amount of money that is spent on education; the connection between the low level of funding and the relatively poor performance of schools appears to be obvious. However, it is far from being that trivial. If we can trust the data behind the most important financing-related indicators, we can say that in 
terms of the financing capacity of the country (i.e. as compared to the GDP), the Serbian education system is funded a little bit below the average level of the most developed countries that is caused by the below average level of the compensation of teachers (Teodorovic, 2008). It means that, after removing certain obstacles to the efficient use of financial resources, there will be some limited space for increasing the salary of teachers. However, there is no direct connection between the level of financing and the effectiveness of education. To put it very simple, if teachers earn more, they will not automatically teach better. As a consequence, we cannot expect that by increasing teachers' salaries, the number of students who are failing will decline. (The same applies to any other recurrent cost of education.) There is a connection between financing and school failure but it is independent from the mainstream allocation system: the serious shortage of resources for development and for professional support services. The "project budget lines" at the disposal of the Ministry of Education and the resources made available by international donor agencies are far from being sufficient to allow for much needed developments. (We will return to its consequences for policy-making in Serbia.)

There are two other major governance failures to be mentioned that contribute to high school failure: the insufficient professional development of teachers and the insufficient offer of professional support services. The fact that teachers are not fully prepared for the use of the pedagogical tool-kit of differentiated (individualized) teaching is already established by their initial training. In the course of the Bologna process the weight of courses preparing for the core competencies of the teaching profession was increased to 36 credits for subject teachers but it is still very slim. But even if it were much higher, investing to initial training would bring results only in a very long run. Therefore, what would be essential is the capacity of the government to implement large scale in-service training programs embedded into school development programs. This is the matter that connects the problems of professional development and professional support services.

Education is one of the most knowledge-intensive service sectors. Knowledge needs of any kind of change in schools are tremendous; this is the reason why schools consume various professional support services everywhere, which are provided to the whole school (external assessment, evaluation, etc.), to school directors (coaching, consulting, etc.), to teachers (in-service training, consulting, etc.) and students (individual development, logopedia, etc.). Especially, when implementing school development focused large scale development programs, the demand for professional support increases far beyond the intensity of "normal times". The professional support system in Serbia is based on three poorly connected networks: (i) the advisors of the Regional Departments (typically subject specialists), (ii) professionals employed by schools (such as "pedagogues", psychologists, etc.) 
and (iii) the network of NGOs and international donor agencies. In general, the public sector of this system (advisors and school professionals) works in an organizational setting that does not allow for professionalization and clear service provider - client relationships, and neither the public nor the NGO sector can reach out to the critical mass of schools. All these characteristics have two consequences: weak knowledge transfer to teachers and schools and insufficient capacities for supporting teachers in identifying children with learning difficulties and in their individual development.

\section{The educational policy implications: back to the foundations}

\section{Policy objectives}

So far we have identified two fairly interlocked patterns of school failure in Serbia: the relatively weak capacity of the education system to enrol and retain students throughout the mandatory period of schooling and the weak foundations (basic competencies) of students with major consequences for their further learning chances. The roots of both sets of problems are very much common; they flow from the characteristics of teaching and the operation of schools, as well as from the interplay of various governance failures.

As far as the relevant package of policy interventions is concerned, certain underlying assumptions are to be considered. While saying that, at this level of generality of the discussion so far, the reasons for weak retention capacity and poor learning outcomes are the same, we can not take for granted that interventions aiming at maximizing enrolment and mitigating dropout will automatically result in improved learning outcomes for several reasons. First of all, there are various weaknesses and shortcomings contributing to the attritive character of education in Serbia, that, even if removed, it is unlikely that the alignment and method of teaching will change. For example, if the vested interest of municipalities and schools in students' retention is strengthened, the outcome will be the simple transformation of one kind of failure (i.e. dropout) to another one (i.e. functional illiteracy).

Another consideration to be mentioned is the different timeframe of improvement in relation to the two types of failure. Increasing enrolment and reducing dropout is a feasible mid-term objective. However, building the pedagogical preparedness of schools to compensate for the negative impact of disadvantages on learning requires a deep paradigm shift that takes much more time. For example, re-tracking special educational needs children (whatever that implies on the basis of the underlying taxonomy that is in use) to mainstream integrated settings is one thing; overcoming the possible negative effects of "rigid integration" (i.e. making education more inclusive) is another, and a much more time-consuming development. The third aspect to keep in mind refers to various, hardly avoidable negative 
effects of improved retention. For example, if more Roma children are kept in schools for a much longer period of time, the stronger "white flight" (nonRoma parents bringing their children to other schools when the proportion of Roma children reaches a certain level) is expected. This and other possible effects of keeping disadvantaged children in schools longer will increase the social and ethnic split (i.e. selection) within the education system, with a very high probability that will increase the magnitude of achievement failures and reduce the overall average performance of the system at the measurement point of PISA.

All these considerations suggest that the hopefully transitory period of improved participation and further declined (in a good case: stagnating) learning performance, that is, the profile of the recent very selective Bulgarian education system, cannot be spared. Higher selection and a still high proportion of students leaving schools with a hardly acceptable level of basic competencies appear to be the price that the Serbian education system will have to pay for a universal opportunity for children to learn. (The possible theoretical alternative of jettisoning a big proportion of students and concentrating on the improved learning of those who survive the initial phase of education is neither feasible nor morally acceptable.) The conclusion for the adequate policy goals is a distinction between medium-term and long-term objectives; in the near future the emphasis should be placed on participation (improved enrolment and retention), while in the long run the reduction of selection and the improvement of effectiveness should be addressed.

When making the distinction between the two sets of policy objectives we do not suggest at all that the two policies are sequential, or cannot be pursued parallel. Quite on the contrary, they should be addressed at the same time for two major reasons: (i) there are certain policy instruments to be applied for both purposes (such as strengthening school preparedness of children by much bigger pre-school enrolment and by improving learning foundations in the initial phase of primary education) and (ii) as it will be seen later, the creation of the systemic and school organization related conditions of the much needed pedagogical paradigm shift is a time consuming investment in itself. Therefore, the proposed distinction between participation (equal opportunities) and learning outcomes (equity) related goals is rather about the different necessary emphasis of goals with changing dynamics over time. In addition to these, focusing on the foundations of learning in early stages should not imply ignoring intervention in later stages. For example, making classroom teaching more effective without investing into the individualization of subject teaching would make the gap between the two phases even more dramatic, as it actually is. Also, due to the large number of student failing, a much richer supply of second chance programs is essential. Nevertheless, priorities are to be set and the appropriate long-term investment emphasizing the foundations of learning pathways. 
To sum it all up, within the specific context of Serbia in the forthcoming years, educational policies are worth to pursue objectives on the basis of a "back to the foundations" approach in three different senses: (i) the attritive character of the system is to be overcome by improved participation indicators, (ii) the initial stages of education (pre-school and classroom teaching) are to be placed in the centre of educational policies and (iii) much bigger emphasis should be given to the development of those basic reading, mathematic and science competencies that establish the foundations for learning success at later stages.

\section{Policy design}

Similar to the problems to be addressed by the appropriate educational policy interventions, the way policies are made and implemented is very much contextual. The design of policies aiming at reducing school failure should fit the capacities of the government to solve problems effectively. In this respect, the most important characteristic of governance of education in Serbia is the fact that the Ministry of Education cannot handle a comprehensive system overhaul. Of course, there is no government able to implement too many parallel systemic reforms. However, there are certain characteristics of educational policy making in Serbia that make the latitude of government intervention even more limited: (i) lacking practice of setting unambiguous and concrete priorities, (ii) weak implementation capacity of the Ministry of Education and (iii) lack of sufficient financial resources for policy intervention and development.

In spite of the fact that a large number of education-related strategic documents were approved ${ }^{6}$ in Serbia, or just due to strategy overload, the actual priorities of the government are not really visible and poorly orient the actors of education. Setting clear-cut priorities (that is, selecting among the large number of intervention needs) would require a much stronger policy coordination mechanism at the level of government on the one hand, and within the Ministry of Education on the other. In addition to that, due to the lack of the most effective implementation instruments (such as financial incentives, research and development agencies, professional support capacities reaching out to all schools, etc.) the ruling pattern of implementation is regulation (laws and rulebooks) combined with small scale projects (in fact, pilot projects in a very limited number of schools). Even if

6 "Quality education for all", the Poverty Reduction Strategy, the strategy of the Ministry of Education for 2005-2010, the Adult Education Development Strategy, the Vocational Education Development Strategy, the National Action Plan for Children, the revised Roma Education Action Plan, the National Strategy of Economic Development, the National Strategy of Serbia's Accession to EU and the Strategy for the Improvement of the Position of Persons with Disabilities. 
institutional and professional conditions of policy implementation were much more developed, the government almost completely relies on the financial resources of international donor agencies that have their own development agendas, not always in line with that of the Ministry of Education. Public budget contribution in Serbia to the implementation of any educational policy is rather symbolic.

Bearing in mind the limited policy-making and implementation capacity of the government, it would not be realistic to design very ambitious policies in relation to the much needed reduction of school failures of any sort. Contrary to this, we saw earlier that the government faces the double challenge of enhancing the retention capacity of education and reducing the negative impact of disadvantages on learning outcomes. These challenges require a long-term sustained effort and major systemic reforms. The problem is further complicated by the "stop and go" nature of policy-making; government initiatives and developmental priorities rarely survive more than one government term. In these circumstances, a strong focus of policies is even more essential.

On the whole, four types of interventions seem to be desired and feasible: (i) making all forms of school failure visible, (ii) increasing pre-school enrolment, (iii) developing effective dropout prevention regimes in schools and (iv) better connecting ongoing systemic changes with the problem of school failure. The first two packages of interventions may well serve the medium and long-term objectives, too. The third one is a focused and easily communicated pile of concrete interplaying measures. The fourth package contains developments that are designed to ensure that the already ongoing changes will be instrumental in combating all forms of educational inequalities.

Making all forms of school failure visible. The often returning complaint on these pages about the lack of basic statistical data is not the "private matter" of researchers and analysts; without reliable and publicly available basic statistical information, the local actors of education (municipalities and schools) cannot be held accountable for full enrolment and successful retention of children. Even a serious effort to place the reporting and registration system in order delivers a message that local level actors will decode as effectiveness expectations. Also, without this information, national and regional administration, as well as the external evaluation of schools, will remain feeble. In years to come, the same should apply to the information on the achievement of students without which individual schools cannot be held accountable. The best possible way is to develop an external standardized assessment system (i.e. annual testing of eighth grade students) on the basis of standards. An additional requirement is investing more in the knowledge basis of policy-making by commissioning empirical research in order to reveal the hidden reasons for all forms of school failure and in independent policy and program evaluation in order ensure better understanding about 
what really works. Various ongoing developments may improve the situation in the near future.

Increasing pre-school enrolment. This matter is already on the policy agenda of the recent government. The two major interventions that are required for achieving much higher pre-school enrolment comprise strengthening the role of municipalities in ensuring pre-school enrolment (that involves stronger administrative mandates and improved local population registration) and the expansion of the available pre-school capacities (by earmarked resources deployed to municipalities and by training of pre-school teachers). Of course, increasing pre-school capacities requires big financial investments. Apart from these basic conditions, various social incentives and extending the mandatory pre-school period to one year are worth to be considered. These developments also contribute to the creation of a dropout prevention system.

Developing effective dropout prevention regimes in schools. A comprehensive policy that aims at reducing dropout in Serbia may consist of four key elements:

- Strengthening the administrative responsibility of parents, municipalities and schools for enrolment and school attendance during the period of mandatory schooling.

- Creating vested interests in retention of students by introducing per capita based normative financing as soon as possible. During the period until its full implementation, communicating the possible consequences of the new financing system is essential.

- Creating effective dropout prevention practices in primary schools (i.e. identification of students at risk of falling out and their individual, tailor-made supplementary support).

- Development programs aiming at promoting the individualization of classroom teaching during the first four years of primary education.

Apart from these policies it is worth considering the increase of mandatory schooling period to the age of 16 , which is the typical mandatory period in Europe.

Better connecting ongoing systemic changes with the problem of school failure. There are certain ongoing systemic changes that have the potential to strengthen the aspects of equal opportunities and equity. For example, as already mentioned, setting minimum performance requirements for all children is a basic requirement of equity in education. The standards have already approved for the eighth grade, and the standards that will be developed for the fourth grade are appropriate instruments. However, in order to fulfil this function, the standards should not set high (i.e. elitist) requirements 
and should be oriented towards the development of key competencies. The assessment of standards in this respect and their revision if required would be an important policy initiative. Another ongoing process is the development of the new instrument (guidelines) for external school evaluation (inspection). It would be important to pay special attention to the evaluation criteria and indicators in relation to the various forms of school failure. The last example for connections of this sort is the reform of initial teacher training; the increment of the weight of "pedagogy" is not necessarily a good investment if it is deployed to subject teaching and not to the development of instruction and assessment repertoire of future teachers.

\section{The alignment of policies}

A comparative analysis of policies aiming at reducing inequities in education in Austria, the Czech Republic, Hungary, Slovakia and Slovenia revealed that the prevailing policy pattern in all of these countries was addressing the education of various student groups (e.g. Roma, immigrants, etc.) by targeted measures. These policies were rather ineffective because they left untouched those major characteristics of primary and secondary education that caused inequities. This finding led to the distinction between policies of "mainstream" and those of "supplementary" character (Radó, 2009). Mainstream policies include changes in the whole education system that, intentionally or not, have an impact on the equity of the system, or on the conditions that allow for the implementation of other policies aimed at making the system more equitable. (The term 'mainstream policy' is not identical with the widely used term "mainstreaming" meaning the integration and inclusion of particular students groups. Nevertheless, in most cases, successful mainstreaming is the result of successful mainstream policies.) Supplementary policies are targeting certain student groups or may target entire levels or segments of the system for the purpose of solving specific problems of particular students groups. In mainstream policies the self-evaluation based school improvement efforts by the staff and management of schools is in focus, while in supplementary policies additional support provided to students, teachers, schools and other actors on the basis of the classification of targeted student groups is in focus. In other words, mainstream policies are aiming at improving equity across the entire system, supplementary policies are aiming at improving the learning success of specific student groups.

The reason why this distinction is important is the common experience of countries with high social sorting of students (that applies both to selective and attritive education systems) that only mainstream policies have the potential of creating an educational environment within which targeted supplementary measures can be effective. If we look at an indicative list of contemporary policy initiatives of the Serbian government (that is far from being complete), it appears to be rather balanced (See: Table 3). However, as 
it was discussed earlier, this balance exists only if mainstream changes are well connected with equity objectives. In this respect, the overall picture is ambivalent; there are initiatives which pay special attention to equity (e.g. the incorporation of an inclusion index to school self-evaluation), but there are others that Serbian experts regard less instrumental in this respect (e.g. the still subject knowledge oriented standards for eighth grade). Nevertheless, the discussion about mainstream policies is still very much disconnected from the theme of inequalities; the professional discourse on equal opportunities and equity is dominated by the topic of various supplementary measures. (We should be reminded here again that policy initiatives and new regulations are far from being implemented policies.)

Table 3: The mix of policy initiatives of the Serbian government

\begin{tabular}{|c|c|}
\hline "Mainstream" policies & "Supplementary" policies \\
\hline $\begin{array}{l}\text { - Mandatory preparatory pre-school } \\
\text { enrolment. } \\
\text { - Standards for eighth grade in } \\
\text { Mathematics, Serbian Language and } \\
\text { Science. } \\
\text { - The revision of the curriculum (Plan } \\
\text { and Program) on the basis of the } \\
\text { standards. } \\
\text { - Preparation of new legislation on } \\
\text { textbook publishing. } \\
\text { - The implementation of the approved } \\
\text { manual on self-evaluation in schools. } \\
\text { - The reform of external school } \\
\text { evaluation. } \\
\text { - The introduction of formula-based } \\
\text { normative financial allocation system. } \\
\text { - The "Bologna compatible" reform of } \\
\text { initial teacher training. }\end{array}$ & 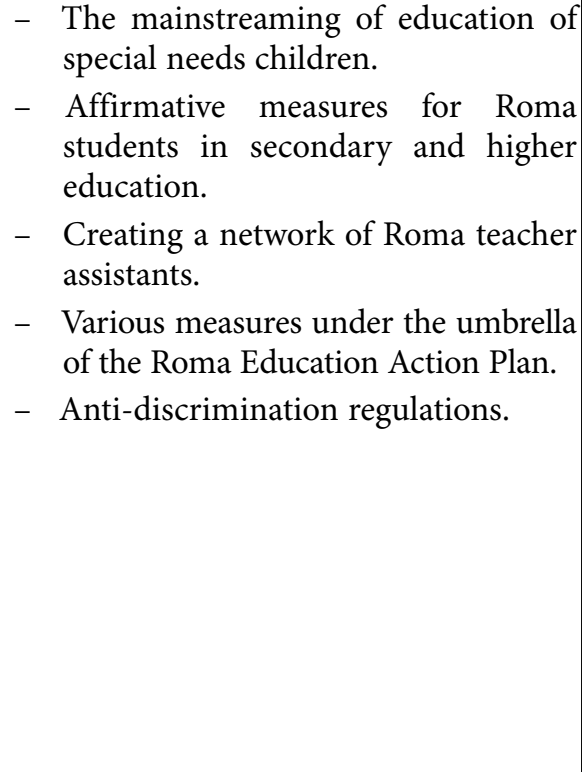 \\
\hline
\end{tabular}

The trap embedded into the situation in Serbia is that high dropout appears to be a "Roma problem", while low performance appears to be a "quality problem". This creates a double discourse that is a policy replication of the double standards, which very much characterizes the education of Roma children. However, this distinction is meaningless, even if a large proportion of dropouts were Roma indeed. (As it was mentioned earlier, we do not really know who the dropouts and out-of-school children are.) Whatever supplementary and targeted instruments are used in order to improve the education of Roma students, the genuine educational capacity of schools to deliver for children with any background will not necessarily improve. Therefore, bigger emphasis should be placed on "colour blinded" developments, and the scope of "colour conscious" supplementary support 
should be limited to the non-educational factors of the failure of Roma students, such as discrimination and minority rights.

\section{Conclusions: the relevance of OECD recommendations in Serbia}

Finally, having briefly described the contextual features of the Serbian education system in relation to various forms of school failure, it is time to look at the relevance of OECD equity recommendations (See: Table 4). The composition of the recommended policies is very much rooted in the composition of the European countries ${ }^{7}$ that participated in the OECD equity project. The common characteristics of the education systems of most of these countries are different from the above-discussed characteristics of education in Serbia in two major respects: (i) dropout rates are much lower and the majority of dropouts are falling out at much later stages (basically in uppersecondary education) and (ii) the proportion of 15 year old students with extremely poor basic competencies is significantly lower. (Of course, as it was indicated earlier, there are rather big differences between the Northern, North-Western European and the CentralEuropean countries.) Therefore, the OECD recommendations place a bigger emphasis on dropout prevention in secondary education (e.g. on good career guidance, as well as flexible and diverse options in secondary education) and on reducing unfair selection of the students.

Table 4: The Ten Steps. The OECD policy recommendations for equity in education (OECD, 2007)

\begin{tabular}{|c|c|c|}
\hline Design & Practices & Resources \\
\hline 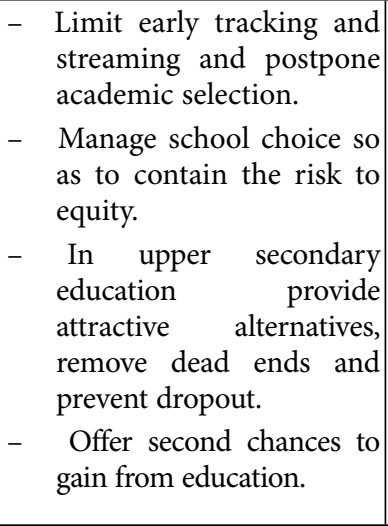 & 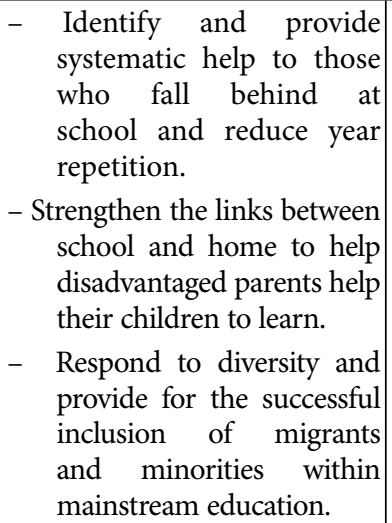 & $\begin{array}{l}\text { - Provide strong education } \\
\text { for all, giving priority to } \\
\text { early childhood provision } \\
\text { and basic schooling. } \\
\text { - Direct resources to students } \\
\text { and regions with the } \\
\text { greatest needs. } \\
\text { - Set concrete targets for } \\
\text { more equity, particularly } \\
\text { related to low school } \\
\text { attainment and dropouts. }\end{array}$ \\
\hline
\end{tabular}

7 The participating countries were: Belgium (Flanders), Finland, France, Hungary, Norway, The Russian Federation, Slovenia, Spain, Sweden and Switzerland. 
The concluding remark of this paper is that apart from these contextual differences the majority of the OECD recommendations are very much relevant for Serbia. In addition to this, even those recommendations that do not fit the recent intervention needs will gain relevance if a mid-term "back to the basics" type of policy results in the reduced primary dropout and improved quality of the initial phase of education.

\section{References}

Bischoff, C. (2009). Financing systems for better schools. In C. Bischoff (ed.), Public Money for public schools: Financing education in southeastern Europe (pp. 1-20). Budapest: LGI/OSI.

Field, S., Kuczera, M., Pont, B. (2007). No more failure: Ten steps to equity in education. Paris: OECD.

OSI/EU Monitoring and Advocacy Program (2007). Equal access to quality education for Roma - Monitoring report. Budapest: Open Society Institute, EU Monitoring and Advocacy Program.

European Centre for the Development of Vocational Training (2003). Lifelong learning: citizens' views. Luxemburg: Office for Official Publications of the European Communities.

OECD PISA (2006). PISA 2006 results. Tables, figures, annex materials and online database. (http://www.oecd.org/document/2/0,3343,en_32252351_32236191_39 718850_1_1_1_1,00.html)

Martin, M. O., Mullis, I. V. S.; Kennedy, A. M., and Foy, P. (2007). PIRLS 2006 International report - IEA's progress in international reading literacy study in primary schools in 40 countries. Chestnut Hill, MA: TIMSS \& PIRLS International Study Center, Boston College.

Commission of the European Communities (2008). Commission staff working document - Progress towards the Lisbon objectives in education and training. Indicators and benchmarks 2008. Brussels: Commission of the European Communities.

Radó, P. (2009). Equity in education - Synthesis report: the potential and limitations of the learning outcomes based approach. Policy-making for equity in education in Austria, the Czech Republic, Hungary, Slovakia and Slovenia. In Simon P. et al. (eds.), Equity in education: Country notes of a Central-European project 2009 (pp. 153-196). Budapest: Tempus Public Foundation.

Radó, P. (2010). Governing decentralized education systems: Systemic change in the southeast European context. Budapest: Open Society Institute Budapest (In print).

Rosenthal, R. and Jacobson, L. (1968). Pygmalion in the classroom: Teacher expectation and pupils intellectual development. New York: Holt, Rinehart and Winston.

Schwab, K., Porter, M. E. and Sachs, J.D. (2002). The global competitiveness report 2001-2002. Oxford: World Economic Forum and Oxford University Press.

Teodorovic, J. (2008). Comparative study of the financing systems of primary and secondary education in the republic of Serbia and in selected countries. (Manuscript) 
UNDP (2005). Vulnerable groups in central and southeastern Europe. Bratislava: UNDP. Winch, C. and Gingel, J. (1999). Key concepts of the philosophy of education. London: Routledge.

World Bank (2007). The labor market and education and training in the western Balkans - a policy note. Washington:World Bank.

CEDEFOP (2008). The shift to learning outcomes. Conceptual, political and practical developments in Europe. Luxembourg: Office for Official Publications of theEuropean Communities.

Tomlinson, C. A. (1999): The differentiated classroom: Responding to the needs of all learners. Alexandra, USA: Association for Supervision and Curriculum Development.

DATUM PRIHVATANJA RADA 2.6.2010

\section{Školski neuspeh u Srbiji}

\section{Peter Rado}

Expanzio Consulting Ltd., Mađarska

Cilj ovog rada jeste da u Srbiji unapredi razvoj diskursa o jednoj od najznačajnijih karakteristika osnovnog i srednjeg obrazovanja: o visokoj proporciji učenika koji su neuspešni na različite načine. Nalazi su uglavnom zasnovani na međunarodnoj komparativnoj analizi koja ukazuje na postojanje tri evropska obrasca pravednosti u obrazovanju: kompenzatorni obrazovni sistemi, koje karakteriše visok stepen pravednosti (nizak uticaj socio-ekonomskog statusa, nezahtevni selekcioni kriterijumi) i visok kvalitet (natprosečna postignuća učenika), selektivni obrazovni sistemi, u kojima nizak nivo pravednosti i stroga selekcija rezultiraju postignućima učenika koja su ispod proseka i atritivni obrazovni sistemi (u koje spada Srbija i većina zemalja jugoistočne Evrope), koje karakteriše izražena nepravednost i relativno slab prosečan kvalitet, uz visoku proporciju učenika koji su neuspešni kako u pogledu redovnosti školovanja tako i u pogledu kvaliteta obrazovnih postignuća. U tekstu se daju smernice za buduća empirijska istraživanja tako što se razmatraju mogući uzroci školskog neuspeha i analiziraju implikacije obrazovne politike u okviru specifičnog konteksta Srbije.

Ključne reči: komparativna analiza obrazovanja, obrazovna politika, atritivno obrazovanje, školski neuspeh. 